\title{
Sustainable Development of Supply Chain in Footwear Industry - Take Nike as the Case
}

\author{
Wenjie Jiang $^{1}$ \\ ${ }^{1}$ Monash University, Mel, VIC, Australia \\ Correspondence: Wenjie Jiang, Monash University, Mel, VIC, Australia.
}

Received: November 8, 2019

Accepted: December 5, 2019

Online Published: December 14, 2019

doi:10.20849/abr.v4i3.690

URL: https://doi.org/10.20849/abr.v4i3.690

\begin{abstract}
Rapid growth in demand for designer shoes, rising per capita incomes in developed and developing economies, and the growing popularity of high-end customers and athletic shoes among men have led to a growing global demand for fashionable and comfortable footwear of all ages (FELTON, 2018). The market share of footwear industry has expanded rapidly which attracted more and more new entrants. However, the competition of shoe industry more incline to the competition of the supply chain, so, it is essential to maintain a certain competitiveness in terms of supply chain. Sustainable development is an emerging but important topic. Some processes of the supply chain of the sportswear industry have been accused of restricting its development, such as the use of polluting raw materials and sweatshops. Supply chain development should not only focus on the economic level, but also pay more attention to the environmental and social aspects of sustainable development. Therefore, this paper will take Nike, the most representative company in the footwear industry, as the analysis target to reflect the development of the supply chain of the footwear industry.

This paper will start with the general analysis of the footwear industry, followed by considering the industry change; then, analyse Nike's core product - Nike Flyknit. Further, before making the conclusion, this paper will explore the impact of external factors, i.e. Nike's cooperation with the US government and footwear related associations, on its supply chain development.
\end{abstract}

Keywords: supply chain management, sustainability, footwear industry change, Nike Flyknit

\section{Industry Analysis}

As a mature industry, footwear industry is composed of some giant company like Nike and Adidas, and millions of small retailers. The main activities of members in the industry is wholesale shoes, industry companies wholesale a range of footwear products including all types and categories of men's, women's and children's shoes to retailers. Most footwear wholesalers also conduct sales and administrative activities, such as managing the storage and transportation of stock, developing marketing and advertising materials and establishing relationships with manufacturers and retailers (Claudia, 2019). In the footwear industry, the key buyers are taken as individual consumers, and footwear manufacturers as the key suppliers. There are some giant footwear company and managed to dominate market share in the footwear industry. Take Australian footwear industry; for example, according to the research of Claudia (2019), Nike has the biggest market share of 9.5\%, Adidas has $8.8 \%$, and Accent $5.7 \%$, while other $76 \%$ was consist of millions of small companies. Next, this report will analyse the footwear industry through Porter's Five Force model to gain a holistic view of the market.

\section{Industry competition - High}

In 2020, the global footwear market is forecast to have a value of $\$ 358,583.8$ million, an increase of $32.7 \%$ since 2015 (MarketLine, 2016). Therefore, the competition amongst firms is extremely high and mostly being non-price (Essay, 2018). Internally, companies compete on the basis of price, product range and quality, externally, the industry is subject to strong competition from manufacturers who supply directly to the end market and bypass the wholesale process. The competition in this industry is mostly non-price at least for the established legendary players like Nike and Adidas. They compete for mind share of the customer and aspects like marketing campaigns, brand ambassadors, product proliferation and branding, spell success. Once customers feel satisfactory, the brand stickiness can improve and bring a bigger market share for companies. 


\section{Threat of new entrants - Moderate}

In the footwear industry, brand loyalty is extremely high; economies of scale and scope also restrict entry for small players as the industry is dominated by a few giant players who reap huge benefits from the volumes and the supply chain integration. Furthermore, existing contracts and agreements among established retailers and wholesalers can make it difficult for new wholesaling companies to gain clients. A new entrant will find that it is difficult to find suppliers or raw materials. Despite the potential obstacles presented by the industry's competition, the industry's key investment costs are generally not exorbitant, and it would generally encourage new players to enter the industry.

\section{Threat of substitutes - Low}

Actually, in the whole footwear industry, there are many kinds of shoes. However, for athletic shoes, there are few substitutes. The substitution is quite low as it is not possible for sneakers to be replaced by fashion or high- heeled shoes. Similarly, between tennis shoes and running shoes, there cannot be a replacement.

\section{Bargaining power of buyers - Moderate}

For buyers, the switching cost is very low, unless their brand loyalty is extremely high, as there are so many choices. Also, buyers can find products by online shopping. In order to understand the mind of customers, billions are spent by big players on market research and studying consumer profiling and buying patterns (Essay, 2018). It means that buyers have high bargaining power in the market.

\section{Bargaining power of suppliers - Low}

Major raw materials used in the production of footwear include synthetic rubber, plastic compounds, nylon, leather, polyurethane and canvas (MarketLine, 2016). The giants like Nike and Adidas lay out stringiest norms which a supplier has to comply with in order to mean quality (Glenn, Debra, \& David, 2013). The switching of suppliers in footwear industry is also very frequently. In this situation, the power of suppliers is low, these suppliers work at norms and prices governed by the big players of the industry.

\section{Industry Changes}

Green Operation is simply the rethinking, or more accurately, being more mindful of how organizations are operating with respect to the environment. In the past years, green operation has become increasingly important to the footwear industry. Footwear companies, led by Nike, have been pursuing green production and selling green products since 2005 (Glenn et al, 2013). Nike provide an index to measure how environmentally friendly are the materials. After that, footwear industry began to use more environmentally preferred materials, and reduced toxic chemicals and waste. The environment in their contract manufacturer factories also were required to be environmentally friendly and apply the measuring index.

Triple bottom line is an accounting framework that incorporates three dimensions - social, environment and financial - to measure sustainability performance (Timothy, \& Tanya, 2011). It went beyond the traditional measures of profits, return on investment, and shareholder value to include environmental and social dimensions. Interest in triple bottom line accounting has been growing across for-profit, non-profit and government sectors, the same as footwear industry. Due to the TBL and its core values of sustainability, TBL has become compelling in the business world. For example, reducing waste from packaging can also reduce costs. Therefore, many companies in footwear industry have adopted the TBL sustainability framework to evaluate their performance. Some companies even identified the following variables for their TBL scorecard: amount of taxes paid in economic dimension, charitable contributions and average hours of employee in social dimension, water consumption, greenhouse gas emissions and use of post-consumer and industrial recycled material in Environmental dimension.

The closed loop supply chain is integrated by Eren et al., and aim to minimize transportation, purchases, renovation, and operation costs of disassembly workstations (Jorge et al., 2014). Enterprises can directly obtain economic benefits from closed-loop supply chain management of products. Therefore, closed supply chain is applied more and more in the footwear industry, companies can obtain packaging materials and used raw materials. In addition, any logistics involved after the point of sale to recapture value and ensure proper disposal of the returned product, is called reverse logistics (Shraddha, 2019). Reverse logistics is a good way to decrease the control the cost. Meanwhile, it can also improve the brand image and customer loyalty. For example, Nike takes back worn-out shoes and grinds them to make a new material called Nike Grind which is used to high quality basketball courts, turfs, tracks and more. The customers do not get anything in return, however the environmental benefit associated with it incentivizes people to buy the shoes (Shraddha, 2019). As a result, the footwear industry begins to consider the usage of reverse logistics. 


\section{Product Analysis - Nike}

The main product produced by Nike company is footwear. Klimovski (2016) has claimed that Nike's $80 \%$ footwear used sustainable and recycled materials by the end of 2015, which indicates Nike's footwear development trend regarding to sustainability in recent decades. The first attempt began in 2008 when Nike launched Jordan XX3, which was made of environmentally friendly materials and eliminated chemical adhesives, to achieve the goal of creating high-performance sustainable products and embedding sustainability into core products. Then, Nike Flyknit, designed and launched for high-level runners in 2012 Olympics, which opened the way and was the milestone for the sustainable development of Nike footwear, as well as led to changes in footwear demand and affected manufacturers within the supply chain and even Nike's administrative management.

\section{Product Innovation - Nike Flyknit}

"Nike Flyknit" can be seen as a major shift in the design of Nike's footwear. In February 2012, Nike introduced its Flyknit series. The shoes' upper section is made of only polyester yarn, a sock-like feeling, through digital knitting technology, which is not only provides light weight, elasticity and wear resistance for the shoe body, but also solves the problem of poor air permeability of the material itself through the holes formed by the natural interlacing of the thread. Nike Flyknit's launch meant that the main fabric of the upper was shifted from leather and fabric to polyester yarn. Its appearance also overturned the production mode of traditional shoe upper technology and made a considerable reduction of waste (approximately 80 percent) in the shoe-making process of the upper section (Hoyal, 2013).

Nike Flyknit started out as specialty shoes for only Olympic running athletes, but it quickly became a platform for other new Nike shoes because of its sustainable and professional performance. After the great success of the early Flyknit Racer, Nike began to vigorously promote the running shoes series. In addition to the running shoes series, Nike even extended Flyknit technology to its basketball shoes, football shoes and golf shoes. HTM Flyknit Chukka was launched in January 2013, this shoe improves its air permeability and door support. Till December 2013, Kobe 9 Elite with lightweight strength was published; and in Mar 2014, the knit was applied in soccer shoes, Magista and Vapor Ultimate; then, a lighter and more flexible kind, Flyknit Zoom Agility was met the public. Till Fall 2015, there are 28 models, 6 categories of Flyknit series. To February 2016, Golf Chukka with high-top design was pushed out (Klimovski, 2016). While this time, Nike footwear has undergone a major reform, referring to striving to build Flyknit into wear-resistant, light, stretchable shoes, and each shoe has different needs. Because these Nike Flyknit shoes are almost woven with line fibres, the waste and environmental damage caused by the cutting of the upper material have been greatly improved.

\section{Administrative Innovation}

Nike did some administrative innovation to improve sustainability, referring to creating indexes (see Appendix 1), which became the base of Higg Index later, that can measure sustainability in the design and production of its products. Nike got its designers to start thinking about sustainability in their product design process. Designers incorporated Considered Index (see Appendix 1) into their design decisions, which allows them to choose the best sustainable material with the lowest impact on the environment. Designers would receive a color rating (see Appendix 3) that can indicate scores regarding to their new designs. Meanwhile, Nike added sustainability to the traditional supply chain metrics (see Appendix 2) that already existed, using it to evaluate manufacturers' performance. Based on the rating criteria, each factory would, like designers, receive a color rating (see Appendix 3 ) that reflected its success level of meeting standards and requirements (Stanford Business, 2013). Thus, in order not to be removed from Nike's manufacturer list, contracted factories need to reach a higher score with their maximum capability.

\section{Process Innovation}

The change toward sustainability in product design and innovation will affect the operation of the supply chain, especially for the manufacturing process. Nike designers' innovation in Flyknit digital knitting broke the pattern that only chemical adhesives can be used in fixing the footwear upper section. This has been followed by increased automation and supply chain efficiency. Since 2015, Nike has been working with high-tech manufacturing company Flex to bring more automated production equipment to labor-intensive footwear production. The Flex factory in Mexico has become one of Nike's most important factories, responsible for Nike's production and providing it with a range of innovative manufacturing technologies. Traditional footwear production requires more than 200 different parts in 10 sizes (Klimovski, 2016), and the cutting and pasting of shoes is usually done by hand. Flex company has developed a new manufacturing process for Nike FlyKnit that automates the bonding process of the shoe, and the fabric is cut directly by a laser. In 2015, this manufacturing process was adopted in the 
manufacturing process of Nike Flynkit series, which greatly improved the production efficiency, reduced the labor cost, and even accelerated the lead time.

\section{Impact on Supply Chain with demand change}

Flyknit dismissed the argument that applying sustainability to design and innovation may reduce the product performance. As the concept of sustainable development becomes familiar to the public, environmental dimension forms one of consumers' purchasing intentions; therefore, Nike Flyknit has become popular and been well received by consumers after its launch (Hoyal, 2013). In the face of demand change brought by Nike's innovative products, the supply chain takes into account Nike's responsibilities, obligations and interests, play its role according to the innovative design of shoes, help to restore the design perfectly into physical objects. By this situation, it is recommended by Bitrock (2019) that the supply chain needs to adopt a responsive strategy to quickly grasp the changes in demand and make an effective response to the changes in time.

\section{The Role of Government}

The United States has the largest footwear market in the world, about 79.85 US dollars in revenue in 2018 (Lim, Ching \& Wong, 2018). As the scale of global business networks continues to grow and become more complex, governments, businesses, and other social organizations are trying to coordinate the forces of globalization. In the free market, the government needs to continuously shape and maintain the institutional environment of enterprises.

Since the 2008 financial crisis, the US government mainly have two strategic roles: one is to promote the process of economic and social development. Second, provide regulatory oversight to ensure the best achievement of social and political goals. Governments can play these roles by setting the rules of the game. Such as play a role as an arbiter of credible practices, well-enforced rules; Acting as an "honest broker" (as in the Nike case with the apparel industry partnership) and "Convener" of multiparty organizations and NGOs (Hill, 2000).

During Obama's time in office, he visited Nike's global headquarters to show America government's support for the Trade Promotion Authority (TPA) and the Trans-Pacific Partnership (TPP). Nike Inc. announced plans to accelerate its investment in U.S. footwear manufacturing if trade promotion authority is approved and the trans-pacific partnership is finalized. The U.S. government's policy of reducing shoe tariffs will enable Nike to accelerate the development of most advanced manufacturing methods and domestic supply chains to stimulate domestic manufacturing in the United States. Nike President and CEO Mark Parker said, "our employees and businesses depend on free trade and the ability to reach athletes and consumers around the world. At the same time, this latest advanced manufacturing model is expected to create as many as 10,000 manufacturing and engineering jobs, thousands of construction jobs, and as many as 40,000 indirect supply chain and service jobs in the United States" (NIKE INC., 2019).

China is the biggest third-party manufacturer in TCF (textile, clothing, footwear) industry. However, Donald Trump's policy of tariffs impose will undoubtedly affect the Nike and the entire supply chain of footwear industry. The trade war with China made the United States exports fell sharply. Increasing tariffs lead to rise commodity prices, reduced demand, profits falling and inflation, and many international companies will have to find alternative factories to reduce the risk of tariff impact, Trump's policy will affect the global economy. Thus, Nike, Adidas and 173 other U.S. footwear retailers signed an open letter to the President and posted it on footwear distribution and retail websites, asking for a rethink of tariffs on Chinese-made shoes.

In the future development of the footwear industry, the government should encourage enterprise to achieve its performance and investment, since multinational enterprise is a major source of workplace, innovation and social well-being, therefore, government should support some funding, tax credits and subsidies. Sustainable businesses, such as Stonyfield Yogurt, Oakhurst Dairy, and Green Mountain Coffee, tend to focus on their responsibility to the environment and societal impact and also tend to recognize that government policies and programs are often necessary to help them fulfil their objectives, and therefore are inclined to try to work with and even partner with government to achieve their goals. It is always important for sustainable businesses to understand how their efforts to achieve profits and to serve a social purpose are both strongly influenced by government policies, and it is always important for sustainable businesses to manage their relationships with government effectively (Gittell, 2012).

For the supply chain, the government's regulatory mechanism is used to achieve a sustainable supply chain blueprint and optimize the internal procedures of the supply chain. According to cooperate with government, for example, to reduce tax obligations and achieve social goals by reducing carbon emissions. In addition, establish a standard of working condition to push multinational company to perform its CSR. 


\section{Industry Association}

With the rapid development of world trade, sustainability has become an important indicator for enterprises to survive in the market. According to Mr. Haanaes (2009): "Simple put, sustainability is a business approach to creating long-term value by taking into consideration how a given organization operates in the ecological, social and economic environment." Sustainability is built on the assumption that developing such strategies foster company longevity.

Nike, as a leader in footwear industry, has long been cooperating with associations related to sustainable development.

\section{Sustainable Apparel Coalition}

The Sustainable Apparel Coalition (SAC) is an industry group of more than 200 leading apparel and footwear brands, retailers, suppliers, academics and NGOs working to reduce the environmental impact of apparel and footwear products (Sustainable Apparel Coalition, n.d.). Nike joined the SAC in 2009. The SAC has its own evaluation tool, the Higgs index. The Higgs index can help Nike accurately measure the sustainable development performance of products, thus helping Nike to improve the direction of the supply chain. In addition, the Higgs index can not only help NIKE choose green and environment-friendly materials as an index, but also help NIKE choose a better partner with a green supply chain, so as to reduce more costs for NIKE and increase its sustainability. This is due to sustainable supply chain management can not only help enterprises focus on supply chain, it has been integrated into the concept of green supply chain management (GSCM) with the need for sustainability, which has become a key strategy for enterprises eager to improve their competitive position and performance (Sarkis, 2006). Therefore, joining SAC provides NIKE with the right development plan for sustainable supply chain development.

\section{The Zero Discharge of Hazardous Chemicals Association}

The ZDHC foundation oversees the ZDHC zero roadmap, a collaboration between major fashion brands, value chain branches and associations. Implement safer chemical management practices worldwide. ZDHC works to eliminate harmful chemicals from the global textile, clothing, leather and shoe industries. This is crucial to the development of Nike. This is because Nike's main production ingredients are polyester, rubber, EVA foam, cotton, synthetic leather and leather (The Ohio State University: Nike Shoes, n.d.). Most of these are chemicals, but shoes are personal items that touch people's skin directly, and Nike is a sports brand, so consumers are more critical of Nike's materials. The ZDHC association helped Nike in the purchase of raw materials, $70 \%$ of which were environmentally friendly rubber and $19 \%$ of polyester fibers were recycled. It greatly reduced the cost of procurement and environmental pollution treatment costs.

\section{Ellen MacArthur Foundation Association}

Nike is a global partner of the Ellen MacArthur Foundation Association, a leading organization working with business, government and academia to build a circular economy framework. Through this partnership, Nike is committed to accelerating its innovation efforts toward a closed-loop future, where innovators are committed to transforming the economy and designing it to be resilient and reproducible. However, companies need to choose their supply chains wisely, because different closed-loop supply chains may apply to different environments, depending on the cost structure of the receiving agent (Closed-Loop Supply Chain Models with Product Remanufacturing, 2004).This is due to the closed-loop supply chain is different in many ways from the forward supply chain. In many cases, these differences are not fully understood and are complicated by many types of product returns, because closed-loop supply chains are rarely seen as value-creating systems, progress is slow and much of the focus is on the operational side rather than the larger strategic issues. These additional activities include traditional forward and reverse supply chain activities. These additional activities include:

1. To obtain the final product from the end user

2. Reverse logistics transfers products from point of use to point of disposal

3. Test, classify, and configure to determine the status of the product and the most economically attractive reuse options

4. Refurbishment makes the most economically attractive options: direct reuse, repair, remanufacturing, recycling, or disposal for re-marketing

5. To create and market refurbished goods and distribute products (The Challenge of Closed-Loop Supply Chains, 2003) 
However, the combination design of the closed-loop supply chain can not only provide companies with the needed flexibility to reduce the logistics costs of their forward and backward activities, but also show continued concern and action on environmental issues. To avoid risks in closed-loop supply chain design, the Ellen MacArthur Foundation Association is able to provide technical support to Nike.

\section{Conclusion}

To sum up, footwear industry is in mature phase. Through porter's five forces analysis, brand stickiness and customer satisfaction are key competitive points. Also, brand loyalty is extremely high and it is easily to make a choice when consumers make an order; as a result, it is difficult for new entrants to enter the industry. This report mainly takes Nike as an example, to illustrate its sustainable and effective supply chain in responding to industry and product change. In addition, according to the role of government and other associations, it is recommended that the government needs to loosen policy on tariffs and provide regulatory mechanisms and three industry associations are actively assisting and developing Nike's sustainable supply chain and footwear industry's sustainability initiatives so that Nike can achieve its company goal and social value.

\section{References}

Bitrock. (2019). Reactive Supply Chain - A modern, state of art and scalable managing system for Supply Chain. Bitrock. Retrieved from https://bitrock.it/blog/reactive-supply-chain/

Claudia, B. F. (2019). Footwear Wholesaling in Australia. IBISWorld. Retrieved from http://clients1.ibisworld.com.au.ezproxy.lib.monash.edu.au/reports/au/industry/default.aspx?entid=377

Closed-Loop Supply Chain Models with Product Remanufacturing. (2004). Management Science, 50(2), 239-252.

Essays, UK. (2018, November). Competition in the footwear industry. Retrieved from https://www.ukessays.com/essays/marketing/competition-in-the-footwear-industry-marketing-essay.php?vr ef $=1$

FELTON. (2018, October 17). Footwear Market is Expected to Grow Owing to the Robust Rise in Fashion Industry Till $2021 \quad$ Million Insights. The Markets Insider. Retrieved from https://markets.businessinsider.com/news/stocks/footwear-market-is-expected-to-grow-owing-to-the-robust -rise-in-fashion-industry-till-2021-million-insights-1027624283

Gittell, R. (2012). The sustainable business case book.

Glenn, C., Debra, S., \& David, B. (2013). Nike: Sustainability and Labor Practices 2008-2013. Retrieved from https://www.gsb.stanford.edu/faculty-research/case-studies/nike-sustainability-labor-practices-2008-2013

Haanaes, K. (2009). Why all businesses should embrace Sustainability Some top companies are leading the way. The International Institute for Management Development (IMD). The World competitiveness Yearbook. Retrieved from https://www. imd.org/contentassets/44380898a141424abb873f8774127bc4/tc082-16_why-all-businesses-should-embrace -sustainability_haanaes_bis.pdf

Hill, T. (2000). Operations Management: Strategic Context and Managerial Analysis. Macmillan Press, Basingstoke.

Hoyal, P. (2013). Nike FlyKnit Racer General Information. Running Shoes Guru. Retrieved from https://www.runningshoesguru.com/2013/02/nike-flyknit-racer-review/

Jorge, R. P. G., Beatriz, H. V., Constantino, G. M. S., Alberto, A. A. L., Ruben, P. G., Ulises, J. M., \& Giner, A. H. (2014). Methodology for Supply Chain Integration: A Case Study in the Artisan Industry of Footwear. Mathematical Problems in Engineering. https://doi.org/10.1155/2014/508314

Klimovski, C. (2016). The Complete History of Nike's Flyknit Technology. Retrieved from Hypebeast: https://hypebeast.com/2016/2/nike-flyknit-technology-history

Lim, C. C., Wong, S. X., \& Ching, K. C. (2018). Liquidity risk of footwear industry in America under firm specific and macroeconomic factors.

MarketLine Industry Profile: Global Footwear. (2016). Footwear Industry Profile: Global, 1-27. Retrieved from http://search.ebscohost.com.ezproxy.lib.monash.edu.au/login.aspx?direct=true\&db=bth\&AN=121487051\& site $=$ ehost-live\&scope $=$ site

NIKE INC. (2019). Policies. Retrieved from https://purpose.nike.com/sustainability-policies 
Ratan, K. (2019). Green Operation Management. Retrieved from https://www.scribd.com/presentation/262237106/Green-Operation-Management

Sarkis, J. (Ed.) (2006). Greening the supply chain. Springer Science \& Business Media.

Shraddha, K. (2019). Importance of Reverse Logistics. Supply Chain Minded. Retrieved from https://supplychainminded.com/importance-reverse-logistics/

Stanford Business. (2013). Nike: Sustainability and Labor Practices 1998-2013.

Sustainable Apparel Coalition. (n.d.). The Nike News. Retrieved from https://purpose.nike.com/partnerships-collaborations

The Challenge of Closed-Loop Supply Chains. (2003). Interfaces, 33(6), 3-6.

The Ohio State University: Nike Shoes. (n.d.). Retrieved from https://u.osu.edu/nikeshoes/raw-materials/

The ZDHC. (n.d.). About ZDHC. The ZDHC. https://www.roadmaptozero.com/about/

Timothy, F. S., \& Tanya, J. H. (2011). The Triple Bottom Line: What Is It and How Does It Work? India Business Review, 86(1). Retrieved from https://www.ibrc.indiana.edu/ibr/2011/spring/article2.html

\section{Appendix}

Appendix 1. Indexes - Measuring Sustainability

\section{Nike Sustainability Indexes}

\begin{tabular}{|c|c|}
\hline Considered Index (CI) & $\begin{array}{l}\text { Evaluated footwear and apparel against environmental } \\
\text { impact of waste, water, energy and toxins. }\end{array}$ \\
\hline $\begin{array}{l}\text { Materials Sustainability Index } \\
\text { (MSI) }\end{array}$ & $\begin{array}{l}\text { A component part of the FSI and ASI and evaluates } \\
\text { materials and material vendors against environmental } \\
\text { impact metrics: (up to) } 50 \% \text { base materials, } 24 \% \text { other } \\
\text { environmental criteria (use of recycled material and } \\
\text { organic content, etc.), } 26 \% \text { environmental indicators } \\
\text { related to material vendors (participation in Nike Water } \\
\text { program, etc.). }\end{array}$ \\
\hline $\begin{array}{l}\text { Footwear Sustainability Index } \\
\text { (FSI) }\end{array}$ & $\begin{array}{l}\text { An evolution of the CI, it incorporates MSI scores and } \\
\text { improved Footwear product evaluation metrics: } 40 \% \\
\text { Materials Sustainability Index score, } 30 \% \text { Manufacturing } \\
\text { Waste score, } 20 \% \text { Manufacturing Solvent score, } 10 \% \\
\text { Manufacturing Energy score. }\end{array}$ \\
\hline $\begin{array}{l}\text { Apparel Sustainability Index } \\
\text { (ASI) }\end{array}$ & $\begin{array}{l}\text { An evolution of the CI, it incorporates MSI scores and } \\
\text { improved apparel product evaluation metrics: } 60 \% \\
\text { Materials Sustainability Index Score, } 40 \% \text { Manufacturing } \\
\text { Waste score. }\end{array}$ \\
\hline Manufacturing Index (MI) & $\begin{array}{l}\text { Measures contract factory performance on a balanced } \\
\text { scorecard including cost, delivery, quality and } \\
\text { sustainability }(25 \% \text { each). Points (out of } 100) \text { lead to } \\
\text { ratings: red }(<60) \text {, yellow }(60-69) \text {, bronze }(70-84) \text {, silver } \\
(85-94) \text {, gold }(95-100) \text {. }\end{array}$ \\
\hline Country Risk Index (CRI) & $\begin{array}{l}\text { Measures sourcing and manufacturing risk at country } \\
\text { level: political, social/compliance, economic, } \\
\text { infrastructure, and climate. }\end{array}$ \\
\hline
\end{tabular}

Source: Nike. 
Appendix 2. Supply Chain Metrics

Rating Criteria (25 points each)

\begin{tabular}{|l|l|}
\hline Quality & $\begin{array}{l}\text { Product issues, defective } \\
\text { rates, manufacturing } \\
\text { processes. }\end{array}$ \\
\hline Delivery & $\begin{array}{l}\text { Delivery precision, planning } \\
\text { precision. }\end{array}$ \\
\hline Costing & $\begin{array}{l}\text { Cost competitiveness, cost } \\
\text { accuracy, cost timeliness. }\end{array}$ \\
\hline Sustainability & $\begin{array}{l}\text { Lean implementations, } \\
\text { environmental/energy, labor, } \\
\text { health and safety. }\end{array}$ \\
\hline
\end{tabular}

Appendix 3. Designer and Manufacturer Rating Color

\section{Score Results}

\begin{tabular}{|l|l|}
\hline Red $(<60$ points) & $\begin{array}{l}\text { Unsuccessful: Immediate } \\
\text { action required. }\end{array}$ \\
\hline Yellow (60-69 points) & $\begin{array}{l}\text { Inconsistent: Below } \\
\text { minimum standards. }\end{array}$ \\
\hline Bronze (70-84 points) & $\begin{array}{l}\text { Meets minimum standards (in } \\
\text { good standing). }\end{array}$ \\
\hline Silver (85-94 points) & $\begin{array}{l}\text { Industry leader: exceeds } \\
\text { standards. }\end{array}$ \\
\hline Gold $(95-100$ points) & $\begin{array}{l}\text { Global role model: far } \\
\text { exceeds standards. }\end{array}$ \\
\hline
\end{tabular}

Source: Nike, http://www.nikeresponsibility.com/infographics/materials/index.html.

\section{Copyrights}

Copyright for this article is retained by the author(s), with first publication rights granted to the journal.

This is an open-access article distributed under the terms and conditions of the Creative Commons Attribution license (http://creativecommons.org/licenses/by/4.0/). 